\title{
Merkantilisme Dalam Perekonomian
}

\author{
Musdalifah \\ 90100118006 \\ Musdalifahippo093@gmail.com
}

Merkantilisme adalah sekumpulan pemikiran ekonomi yang muncul di Eropa selama periode 1500-1750. Negara memiliki tindakan yang sama terhadap aktivitas ekonomi domestik dan peran perdagangan internasional, tujuannya adalah untuk mendominasi ekonomi dan kebijakan pada masa itu. Merkantilisme sering dianggap sebagai political economy of state building. Pusat pemikiran merkantilisme adalah pandangan bahwa kekayaan nasional direfleksikan pada logam berharga yang dimiliki suatu negara yaitu emas.(Putri n.d.)

Baik merkantilisme maupun liberalisme memiliki kelemahan kekuatan. Dasar pemikiran sistem pasar kedua ideologi tersebut adalah untuk meningkatkan kekuatan dan keamanan negara, namun pendekatan mereka terhadap sistem pasar berbeda dan ketegangan antara kedua ideologi tersebut masih terjadi saat ini. Bagi liberalisme, yang paling penting adalah mempromosikan operasi pasar bebas, dan menganggap keberhasilan individu sebagai faktor pendukung bagi kesejahteraan masyarakat universal. Lebih lanjut, liberalisme mencerminkan komitmen terhadap kesetaraan dan kebebasan individu. Sebaliknya, merkantilisme selalu mempertimbangkan prioritas keamanan teritorial negara sebagai prioritas pertama. Mercantris berpendapat bahwa untuk mencapai kemakmuran, keadilan, atau perdamaian domestik, kegiatan ekonomi harus berada di bawah tujuan pembangunan negara dan kepentingan negara. Masalah ekonomi adalah aspek masyarakat dalam kerangka sosiopolitik yang ada sebagaimana diberikan termasuk distribusi hak kekuasaan dan properti.(Utama et al. n.d.)

Para penganut merkantilisme meyakini bahwa untuk memperoleh kekayaan dan kekuatan tersebut dibutuhkan sebuah alat, yaitu perdagangan internasional. Ekspor dan impor memiliki peran yang sangat besar di dalamnya dimana ekspor harus jauh lebih besar sedangkan impor dibatasi dengan seminimal mungkin. Johann Becher, seorang merkantilis asal Jerman menyatakan bahwa lebih baik untuk menjual produk ke negara lain dibandingkan membelinya. Negara harus memproteksi perekonomian negaranya dengan mendorong ekspor melalui insentif dan 
mengurangi impor dengan pemberlakuan tarif yang besar. Tindakan ini akan berhubungan dengan surplus dan defisit neraca perdagangan suatu negara. Surplus yang diperoleh akan mengakibatkan kekuatan nasional, sebaliknya defisit perdagangan akan mengakibatkan melemahnya performa ekonomi dan politik suatu negara (Batubara, 2017).

Pemikiran ekonomi kaum merkantilis merupakan suatu kebijakan yang sangat melindungi industri, dalam negeri, tetapi menganjurkan persaingan, sementara itu terjadi pembatasanpembatasan yang terkontrol dalam kegiatan perdagangan luar negeri, kebijakan kependudukan yang mendorong keluarga dengan banyak anak, kegiatan industri di dalam negeri dengan tingkat upah yang rendah. Proteksi industri yang menganjurkan persaingan dalam negeri, dan tingkat upah yang rendah mendorong ekspor.Mazhab fisiokrat tumbuh sebagai kritik terhadap pemikiran ekonomi Merkantilis, tokoh pemikir yang paling terkenal pada mazhab ini adalah Francois Quesnay. Sumbangan pemikiran yang terbesar dalam perkembangan ilmu ekonomi adalah hukumhukum alamiah, dan menjelaskan arus lingkaran ekonomi (Pujiati, 2011).

\section{Daftar Pustaka}

Putri, Eka Deviana. “Arti Penting Poundsterling Bagi Inggris Dalam Uni Eropa Latar Belakang.” (0911240049).

Utama, Ideologi et al. "Ideologi Utama Dalam Ekonomi Politik Global Antara Merkantilisme Dan Liberalisme."

Batubara, Ernawati. 2017. “Kebijakan Proteksionisme Amerika Serikat Terhadap Republik Rakyat Cina.” Jurusan Ilmu Hubungan Internasional 110(9): 1689-99.

Pujiati, Amin. 2011. "Menuju Pemikiran Ekonomi Ideal: Tinjauan Filosofis Dan Empiris.” Fokus Ekonomi 10(2): 114-25. 